\title{
Alzheimer's Disease: Genes, Pathogenesis and Risk Prediction
}

\author{
K. Sleegers C.M. van Duijn \\ Department of Epidemiology and Biostatistics, Erasmus Medical Centre Rotterdam, The Netherlands
}

\section{Key Words}

Alzheimer's disease - Genetic epidemiology . Pathogenesis - Risk prediction - Genetic counselling . $\beta$-Amyloid

\begin{abstract}
With the aging of western society the contribution to morbidity of diseases of the elderly, such as dementia, will increase exponentially. Thorough preventative and curative strategies are needed to constrain the increasing prevalence of these disabling diseases. Better understanding of the pathogenesis of disease will enable development of therapy, prevention and the identification of high-risk groups in the population. Here, we review the genetic epidemiology of Alzheimer's disease, the most common cause of dementia in the western world. The search for genetic risk factors, though far from completed, has been of major importance for understanding the pathogenesis of Alzheimer's disease. Although effective therapy is still awaited, these findings have led to new avenues for the development of drugs.

Copyright (C2002S. Karger AG, Basel
\end{abstract}

\section{Introduction}

Although in the past century major progress has been made in unravelling the genetics of Alzheimer's disease (AD), many questions remain to be answered. The debates about its pathogenesis, diagnosis, therapy and pre- vention have not been settled yet. It is clear that $A D$ is a complex multifactorial disorder. A great number of possible genetic risk factors have been investigated, but for most of these no clear association has been found [1]. The search for genetic risk factors has yielded three genes (amyloid precursor protein [2-5], presenilin-1 [6-10] and presenilin-2 genes $[11,12]$ ) in which mutations were found which result in rare autosomal dominant forms of AD. One susceptibility gene (apolipoprotein E gene) has been identified which is a risk factor in the general population.

In this paper the prevalence and risk factors for $\mathrm{AD}$ are reviewed. The emphasis will be on the genes known to be involved in $\mathrm{AD}$, their role in understanding the development of the disease, and their implications for diagnosis and clinical counselling.

\section{Clinical Epidemiological Aspects of AD}

\section{Diagnosis and Prognosis}

$\mathrm{AD}$ is the most common cause of dementia in the western world. The disease is clinically characterized by insidious onset and slow progression of cognitive decline. Most frequently, loss of short-term memory and impaired imprinting of new information are the presenting symptoms of AD. During the course of the disease, symptoms may further include disturbance of speech, poor judgment, personality change and deterioration of visuospatial skills, with preserved level of consciousness. Patients gradually lose the ability to be self-supportive, and even-

\begin{tabular}{ll}
\hline KARGER & ( ) 2002 S. Karger AG, Basel \\
Fax +4161306 1234 & 1422-2795/01/0044-0197\$17.50/0 \\
$\begin{array}{l}\text { E-Mail karger@karger.ch } \\
\text { www.karger.com }\end{array}$ & $\begin{array}{l}\text { Accessible online at: } \\
\text { www.karger.com/journals/cmg }\end{array}$
\end{tabular}

C.M. van Duijn, $\mathrm{PhD}$

Department of Epidemiology and Biostatistics, Erasmus Medical Centre Rotterdam PO Box

NL-1738 Rotterdam (The Netherlands)

Tel. +31 10408 7394, Fax +31 10408 9406, E-Mail vanduijn@epib.fgg.eur.nl 
tually they will become bedridden. Death usually occurs due to complications of immobility and malnutrition [13]. The average duration of AD is $8-10$ years, although at old age survival may be shorter. Available therapeutic strategies (cholinesterase inhibitors) are not curative, but may halt the process of decline for half a year to 2 years in the early stages of the disease in a small number of patients [14].

The diagnosis is based on clinical examination and neuropsychological testing. These should yield no clues for systemic or other brain diseases capable of causing dementia, such as vascular dementia and subcortical dementia (NINCDS-ADRDA) [15]. Although the precision of the diagnosis has improved considerably with improvement of neuropsychological tests and neuroimaging, during life only a probable diagnosis can be made, with an accuracy of $80-90 \%$. The definite diagnosis of AD is always based on histopathological findings in the brain [16]: neuritic plaques, neurofibrillary tangles and loss of neurons in hippocampus and cerebral cortex.

The neuritic plaques are composed of aggregations of $\beta$-amyloid, which are surrounded by dystrophic dendrites, microglia and astrocytes. These plaques are located preferentially in limbic and association cortices of the brain, areas important for memory and cognition.

Neurofibrillary tangles consist of intraneuronal aggregations of hyperphosphorylated tau. Tau is a protein that is normally present in adult human brain, where it exerts its function through stabilizing microtubules, which are essential for cell shape and support and intraneuronal transport. Hyperphosphorylated tau destabilizes the microtubule network within neurons. Due to subsequent neuronal dysfunction and deficits in neurotransmitters, normal brain function is impaired [17].

\section{Prevalence of $A D$}

The number of patients affected with AD (prevalence of disease) is remarkably stable in western society. The major determinant of the prevalence of disease is age. Less than $1 \%$ of the people aged 70 years or younger is affected with AD. But with each 5 years' increase in age the prevalence of AD doubles, until by age 90 years up to $30 \%$ is affected [18]. A large European follow-up study has shown that, especially at older age, women are more often affected than men $[19,20]$.

Although AD is considered to be a disease of the elderly, there are patients in whom first symptoms of AD may be present as early as at age 35 years. Frequently, a distinction is made between 'early-onset Alzheimer's disease' (EOAD) and 'late-onset Alzheimer's disease'
(LOAD). The distinction is arbitrary, since clinical and pathological features are very similar in both groups. Age criteria for EOAD vary widely, but usually, when the age at onset of the disease is before 65 years of age, a patient will be diagnosed with EOAD [1].

Given its strong association with age, AD will be an increasing health care problem in the next decades. With the aging of western society, the number of patients is expected to increase exponentially. By the year 2025, over 22 million patients with dementia are expected around the world [21].

\section{Risk Factors}

AD has a complex etiology. Research in the past century has focused on many putative environmental factors that may either increase or decrease the risk of AD. These included age, smoking, maternal age at birth, head trauma, depression, thyroid disease, anti-inflammatory drugs, estrogen replacement therapy, alcohol, occupational exposure, aluminum, education and diet [22]. Findings regarding these risk factors have been inconsistent. Only increasing age and genetic predisposition are consistently correlated with the disease [1].

Perhaps most interesting from an epidemiological perspective is the finding that studies on vascular risk factors such as hypertension, diabetes mellitus, atherosclerosis, and high cholesterol have yielded promising results, showing an up to 2 times increased risk for AD [23-32]. The mechanism through which these vascular factors are associated with $\mathrm{AD}$ remains to be elucidated. It has been argued that these factors may be a primary cause of AD pathology [33]. An alternative explanation may be that vascular pathology is not a primary cause of $\mathrm{AD}$, but rather that it accelerates the primary neurodegenerative process.

The findings of the relationship between vascular pathology and AD are in line with cross-cultural observations by Hendrie et al. [34]. They recently published results on differences in age-standardized annual incidence rates of $\mathrm{AD}$ in an industrialized versus a nonindustrialized country. A possible explanation for the decreased rate in the nonindustrialized country is the lower prevalence of cardiovascular disease in the nonindustrialized population. However, also differences in genetic makeup between populations may partly explain these findings. As discussed in the next chapter, genetic susceptibility is, in addition to increased age, the most important determinant of AD. 


\section{Genetics of AD}

\section{Familial Aggregation}

As opposed to the difficulties encountered in finding environmental risk factors for $\mathrm{AD}$, the genetic component of the disease has long been evident. Epidemiological studies have clearly shown that $\mathrm{AD}$ aggregates within families [35]. First-degree relatives of AD patients have a 3.5 times increased risk of developing AD. The relative risk increases with a decrease in the age at onset of the affected proband. In relatives of patients with an onset before age 70 years the risk of having $\mathrm{AD}$ is increased over 4 times [35]. Concordance rates of up to $80 \%$ have been found in monozygotic twins. In dizygotic twins concordance rates were $35 \%$ [36].

In few families an autosomal dominant pattern of inheritance can be recognized. A segregation analysis suggested an autosomal dominant model in less than $1 \%$ of 198 families with EOAD [37]. In LOAD, it is difficult to make a distinction between a dominant, recessive or additive model of inheritance [38]. In the majority of patients the etiology appears to fit a multifactorial model in which multiple genes and environmental factors interact [1].

\section{Genes Involved in $A D$}

Research on genetic determinants initially focused on families with an autosomal dominant pattern of inheritance. The first dominant mutation was found in the gene encoding the amyloid precursor protein $(A P P)$ on chromosome 21 [2-5]. Up until now, 32 families are known around the world with EOAD due to a dominant $A P P$ mutation (http://molgen-www.uia.ac.be/ADMutations/).

Besides $A P P$, two homologous genes were identified, presenilin-1 (PSEN-1) at chromosome 14 and presenilin-2 (PSEN-2) at chromosome 1q31-q42, which account for families segregating $\mathrm{AD}$ as an autosomal dominant trait as well. So far, more than 80 mutations of the PSEN-1 gene have been identified [6-10] (http://molgenwww.uia.ac.be/ADMutations/). Six mutations in PSEN-2 are described $[11,12]$ (http://molgen-www.uia.ac.be/ADMutations/).

Frequency estimates of these mutations in EOAD patients are highly variable, ranging from less than 1 to $50 \%$ [e.g. 39-41]. Differences might be due to more or less stringent diagnostic criteria in the population under study (e.g. probable vs. autopsy-confirmed AD), different maximum age when considering early onset, and selection of study populations. A study population derived from a highly specialized neurological center is more likely to have an overrepresentation of cases with high familial aggregation. However, in a population-based sample [41] APP mutations were found in only $0.5 \%$ of all EOAD patients and accounted for only $0.005 \%$ of $A D$ in the general population. Although mutations in PSEN- 1 are more common, they still only accounted for $6.5 \%$ of all EOAD patients (i.e. $0.065 \%$ of $\mathrm{AD}$ in the general population). Mutations in PSEN-2 were seen in less than $1 \%$ of all EOAD patients, and less than $0.01 \%$ of the general population. Together, dominant mutations in APP, PSEN-1 and $P S E N-2$ occurred in only $0.075 \%$ of AD patients at the population level [41, 42]. Although these genes have a minor impact in the general population, for the individual carrier the risk is extremely high. Almost all carriers of these mutations express the disease. As EOAD is rare, risk estimates for carriers of these mutations approximate infinity.

In addition to the three autosomal dominant genes, a fourth gene (apolipoprotein E, APOE) was identified which is localized on chromosome 19 and has three common alleles coding for three different isoforms of the protein. The allele frequencies of this gene $(A P O E)$ are 0.08 for $A P O E^{*} 2,0.77$ for $A P O E^{*} 3$ and 0.15 for $A P O E^{*} 4$ in populations of European ancestry [42]. $A P O E^{*} 4$ is strongly associated with LOAD [43, 44] and EOAD [45]. Subjects homozygous for $\mathrm{APOE}^{*} 4$ have an almost 15 times increased risk of developing $\mathrm{AD}$, but $50 \%$ will not develop the disease [46]. Subjects with only one $A P O E^{*} 4$ allele have a moderately increased risk (around 3 times) [47]. Although risks are moderately increased for $A P O E^{*} 4$ for the individual carrier, due to the fact that the allele is common $\mathrm{APOE}^{*} 4$ may explain $17 \%$ of the occurrence of $\mathrm{AD}$ in the general population [42]. Homozygosity for APOE* $^{*}$ contributes less than $2 \%$ to AD because of low prevalence of this genotype $(0.0225)$. It is suggested that $A_{P O E^{*} 4}$ regulates when rather than if the disease occurs $[47,48]$. Due to a relatively earlier onset of LOAD in those homozygous for $A P O E^{*} 4$, the influence of competing morbidity and mortality will be less, thereby enhancing the association between $A P O E^{*} 4$ homozygosity and LOAD.

\section{Genes and the Pathogenesis of AD}

The discovery of mutations in the genes involved in $\mathrm{AD}$ has been of great importance for the understanding of the biological mechanisms underlying AD. All causal mutations affect the normal metabolism of $\beta$-amyloid, suggesting that $\beta$-amyloid constitutes a central event in the pathogenesis of $\mathrm{AD}$. $\beta$-Amyloid, or $\mathrm{A} \beta$, is a peptide present under physiological circumstances in healthy subjects. Due to a mutation in any of the known AD genes, 
the equilibrium between production and clearance of $\mathrm{A} \beta$ gets disturbed, resulting in accumulation of $\mathrm{A} \beta$ in the brain. Amyloid fibrils are formed and subsequently deposited into plaques. At present, the most likely hypothesis is that at first diffuse plaques are formed. These plaques can also be seen in healthy subjects. In AD patients several of these plaques may evolve into 'mature' neuritic plaques containing fibrillar aggregates, damaged neurons and activated glial cells in a cascade of pathological processes, eventually leading to profuse neuronal loss [49-57].

APP is a transmembrane protein that is widely expressed on the cell surface. Its functional properties are not clearly defined, but range from repair of vascular injury to mediation of growth and adhesion of neural and nonneural cells [53]. Recently it has been suggested that APP has a function in the regulation of nuclear transcription [58]. APP is cleaved into A $\beta$. The different mutations that have been found so far in the gene coding for APP are located at or near cleavage sites [40]. By abnormal cleavage of APP larger amounts of a longer version of $A \beta$ are produced, called $A \beta 42$ [59-62]. This longer version is more amyloidogenic and therefore aggregates more easily into plaques [63]. There is increasing evidence that $A \beta 42$ may play a crucial role in the pathogenesis of $\mathrm{AD}$.

The function of the presenilin proteins is unclear, but it has been shown that mutations in PSEN also lead to altered APP processing. A $\beta 42$ levels are raised in brain, plasma and fibroblasts [64] of carriers of a PSEN mutation. Furthermore, in experiments with $P S E N$-transgenic mice and transfected cells higher $\mathrm{A} \beta 42$ levels are found as well [65-68].

In sporadic LOAD the pattern of $\mathrm{A} \beta$ accumulation is less evident. It has been suggested that accumulation is rather the result of impaired clearance of $A \beta$ than of increased synthesis [57]. In carriers of the $A P O E^{*} 4$ allele, the predominant genetic risk factor in sporadic $A D$, APOE has increased affinity for $A \beta$ and $A \beta$ aggregates. Although the precise mechanism has not yet been elucidated, $A P O E^{*} 4$ is suggested to facilitate $\mathrm{A} \beta$ aggregation or to inhibit the elimination of the fibrillar aggregates [44, 69, 70].

Although a body of genetic evidence supports the $A \beta$ cascade hypothesis and although it is the most comprehensive theory so far, the debates on this hypothesis have not been settled yet $[50,57,71,72]$. Disagreement ranges from details within the $A \beta$ hypothesis (e.g. that not the total amount of $A \beta$ is important but rather the relative proportion of $\mathrm{A} \beta 42$ ) to the reverse hypothesis that $\mathrm{A} \beta$ accumulation is a compensatory mechanism to aging [73].
A finding difficult to explain has been that amyloid deposition does not seem to correlate very well with cognitive decline [50]. However, recent findings may have settled this argument by showing that $\mathrm{A} \beta$ plasma levels are elevated early in the course of the disease and are strongly related to cognitive decline, a finding in favor of the $A \beta$ cascade hypothesis $[74,75]$.

While the $\mathrm{A} \beta$ hypothesis is being refined other pathogenic models are considered as plausible. These include hypotheses on the involvement of tau [76], on neuroplasticity [77], aging [72], oxidative stress [78], impaired cerebromicrovascular perfusion [79], inflammation [80] and lipid homeostasis [70].

\section{Genetic Counselling and Risk Prediction}

The identification of genes involved in AD has been a major breakthrough. Yet there is ongoing debate on their use in clinical counselling.

Given the fact that $A P P, P S E N-1$ and PSEN-2 mutations have a virtually complete penetrance and that these mutations are not found in healthy age-matched subjects, one might argue that these mutations are useful for risk prediction and genetic counselling. But the known mutations are only present in a minority of cases. Although mutations can be found frequently in patient populations from highly specialized centers due to selection bias [81], these mutations are rare in the general population. Thus, for risk prediction and counselling, the absence of a known mutation should not be conclusive. Even if the underlying mutation is known in a family with an autosomal dominant form of $\mathrm{AD}$, there is a strong argument against screening relatives at risk, because curative therapy and prevention are not yet at hand. An argument in favor of screening relatives at risk and those that already have dementia without a definite diagnosis might be to take away incertitude and allow for future plans, but screening should always be preceded by thorough counselling, taking into account ethical considerations.

Because of their low frequency, the mutations are not useful as a diagnostic tool for patients with early onset symptoms of dementia [39].

Also the use of $A P O E$ is limited in the clinical practice. $A P O E^{*} 4$ increases the susceptibility to $\mathrm{AD}$, but the increase in risk is modest, especially in the heterozygous carriers of the $A P O E^{*} 4$ allele. As only $50 \%$ of the AD patients carry $A P O E^{*} 4$ and a substantial number of patients with other dementias show similar frequencies, $A P O E^{*} 4$ is not suitable for diagnostic purposes [82]. Even for subjects homozygous for the $A P O E^{*} 4$ allele there is still a $50 \%$ chance not to develop the disease [46]. Thus despite the 
fact that $A P O E$ is a more important determinant of $\mathrm{AD}$ in the general population than $A P P, P S E N-1$ and $P S E N-2$, $A P O E$ is not suitable for risk prediction and counselling.

\section{Considerations}

The discovery of the dominant mutations in the $A P P$, $P S E N-1$ and $P S E N-2$ genes in the families with autosomal dominant EOAD explains only a minor proportion of the disease in the general population. The clinical use is limited and awaits therapy and prevention. Nevertheless, genetic research has made a significant contribution to understanding the pathogenesis of the disease, even in sporadic patients. Genetic evidence is pointing towards a central role for amyloid metabolism in the etiology of AD. Due to the genetic evidence towards $A \beta$ research focusing on $\mathrm{A} \beta$ has expanded impressively. Recently, promising evidence has been found in vaccination strategies with $\mathrm{A} \beta$ in mice, decreasing formation of $\mathrm{A} \beta$ [83] and enhancing cognition in mouse models [84-86]. Verification of these findings in man, combined with useful biomarkers, will be of tremendous importance in the prevention of this disabling disease. Recently, trials in humans were halted because of major side effects.

Meanwhile, other genetic and environmental factors should still be considered to fill the lacunae in our knowledge of AD. Better understanding of the neuropathological mechanisms underlying $\mathrm{AD}$, whether based on genetic findings or on results of other kinds of scientific research, will without a doubt aid future therapeutic and preventive strategies.

\section{Acknowledgment}

This work was supported by the Netherlands Organisation for Scientific Research (NWO).

\section{References}

1 Roks G, Van Duijn CM: Genetic epidemiology of Alzheimer's disease; in Bishop T, Sham PM (eds): Analysis of Multifactorial Diseases. Oxford, Bios, 2000, pp 85-100.

2 St George-Hyslop PH, Tanzi RE, Polinsky RJ, Haines JL, Nee L, Watkins PC, Myers RH, Feldman RG, Pollen D, Drachman D, et al: The genetic defect causing familial Alzheimer's disease maps on chromosome 21. Science 1987;235:885-890.

3 Tanzi RE, Gusella JF, Watkins PC, Bruns GA, St George-Hyslop P, Van Keuren ML, Patterson D, Pagan S, Kurnit DM, Neve RL: Amyloid beta protein gene: cDNA, mRNA distribution, and genetic linkage near the Alzheimer locus. Science 1987;235:880-884.

4 Goate A, Chartier-Harlin MC, Mullan M, Brown J, Crawford F, Fidani L, Giuffra L, Haynes A, Irving N, James L, et al: Segregation of a missense mutation in the amyloid precursor protein gene with familial Alzheimer's disease. Nature 1991;349:704-706.

5 Van Broeckhoven CL: Molecular genetics of Alzheimer disease: Identification of genes and gene mutations. Eur Neurol 1995;35:8-19.

6 Schellenberg GD, Bird TD, Wijsman EM, Orr HT, Anderson L, Nemens E, White JA, Bonnycastle L, Weber JL, Alonso ME, et al: Genetic linkage evidence for a familial Alzheimer's disease locus on chromosome 14. Science 1992; 258:668-671.
7 St George-Hyslop P, Haines J, Rogaev E, Mortilla M, Vaula G, Pericak-Vance M, Foncin JF, Montesi M, Bruni A, Sorbi S, et al: Genetic evidence for a novel familial Alzheimer's disease locus on chromosome 14. Nat Genet 1992;2: 330-334.

8 Mullan M, Houlden H, Windelspecht M, Fidani L, Lombardi C, Diaz P, Rossor M, Crook R, Hardy J, Duff K, et al: A locus for familial early-onset Alzheimer's disease on the long arm of chromosome 14, proximal to the alpha 1antichymotrypsin gene. Nat Genet 1992;2: 340-342.

9 Van Broeckhoven C, Backhovens H, Cruts M, De Winter G, Bruyland M, Cras P, Martin JJ: Mapping of a gene predisposing to early-onset Alzheimer's disease to chromosome 14q24.3. Nat Genet 1992;2:335-339.

10 Sherrington R, Rogaev EI, Liang Y, Rogaeva EA, Levesque G, Ikeda M, Chi H, Lin C, Li G, Holman $\mathrm{K}$, et al: Cloning of a gene bearing missense mutations in early-onset familial Alzheimer's disease. Nature 1995;375:754-760.

11 Levy-Lahad E, Wasco W, Poorkaj P, Romano DM, Oshima J, Pettingell WH, Yu CE, Jondro PD, Schmidt SD, Wang K, et al: Candidate gene for the chromosome 1 familial Alzheimer's disease locus. Science 1995;269:973977.

12 Rogaev EI, Sherrington R, Rogaeva EA, Levesque $\mathrm{G}$, Ikeda M, Liang Y, Chi H, Lin C, Holman K, Tsuda $\mathrm{T}$, et al: Familial Alzheimer's disease in kindreds with missense mutations in a gene on chromosome 1 related to the Alzheimer's disease type 3 gene. Nature 1995;376: 775-778.
13 Cummings JL, Benson DF: Cortical dementias: Alzheimer's disease and other cortical degenerations; in Cummings $\mathrm{JL}$, Benson DF (eds): Dementia: A Clinical Approach. Stoneham, Butterworth-Heinemann, 1992, pp 4593.

14 Giacobini E: Cholinesterase inhibitor therapy stabilizes symptoms of Alzheimer disease. Alzheimer Dis Assoc Disord 2000;14:S3-10.

15 McKhann G, Drachman D, Folstein M, Katzman R, Price D, Stadlan EM: Clinical diagnosis of Alzheimer's disease: Report of the NINCDS-ADRDA Work Group under the auspices of Department of Health and Human Services Task Force on Alzheimer's Disease. Neurology 1984;34:939-944.

16 Braak H, Braak E: Neuropathological stageing of Alzheimer-related changes. Acta Neuropathol 1991;82:239-259.

17 Delacourte A, Buee L: Tau pathology: A marker of neurodegenerative disorders. Curr Opin Neurol 2000;13:371-376.

18 Rocca WA, Hofman A, Brayne C, Breteler MM, Clarke M, Copeland JR, Dartigues JF, Engedal K, Hagnell O, Heeren TJ, et al: Frequency and distribution of Alzheimer's disease in Europe: A collaborative study of 1980-1990 prevalence findings. The EURODEM-Prevalence Research Group. Ann Neurol 1991;30: 381-390. 
19 Lobo A, Launer LJ, Fratiglioni L, Andersen K, Di Carlo A, Breteler MM, Copeland JR, Dartigues JF, Jagger C, Martinez-Lage J, Soininen $\mathrm{H}$, Hofman A: Prevalence of dementia and major subtypes in Europe: A collaborative study of population-based cohorts. Neurologic Diseases in the Elderly Research Group. Neurology 2000;54:S4-9.

20 Fratiglioni L, Launer LJ, Andersen K, Breteler MM, Copeland JR, Dartigues JF, Lobo A, Martinez-Lage J, Soininen H, Hofman A: Incidence of dementia and major subtypes in Europe: A collaborative study of population-based cohorts. Neurologic Diseases in the Elderly Research Group. Neurology 2000;54:S10-15.

21 St George-Hyslop PH: Piecing together Alzheimer's. Sci Am 2000;283:76-83.

22 Van Duijn CM: Epidemiology of the dementias: Recent developments and new approaches. J Neurol Neurosurg Psychiatry 1996; 60:478-488.

23 Skoog I, Lernfelt B, Landahl S, Palmertz B, Andreasson LA, Nilsson L, Persson G, Oden A, Swanborg A: 15-year longitudinal study of blood pressure and dementia. Lancet 1996; 347:1141-1145.

24 Elias MF, Wolf PA, D'Agostino RB, Cobb J, White LR: Untreated blood pressure level is inversely related to cognitive functioning: The Framingham Study. Am J Epidemiol 1993; 138:353-364

25 Ott A, Slooter AJ, Hofman A, Van Harskamp F, Witteman JC, Van Broeckhoven C, Van Duijn CM, Breteler MM: Smoking and risk of dementia and Alzheimer's disease in a population-based cohort study: The Rotterdam Study. Lancet 1998;351:1840-1843.

26 Ott A, Stolk RP, Van Harskamp F, Pols HA Hofman A, Breteler MM: Diabetes mellitus and the risk of dementia: The Rotterdam Study. Neurology 1999;53:1937-1942.

27 Leibson CL, Rocca WA, Hanson VA, Cha R, Kokmen E, O'Brien PC, Palumbo PJ: Risk of dementia among persons with diabetes mellitus: A population-based cohort study. Am J Epidemiol 1997;145:301-308.

28 Lee PN: Smoking and Alzheimer's disease: A review of the epidemiological evidence. Neuroepidemiology 1994;13:131-144.

29 Merchant C, Tang MX, Albert S, Manly J, Stern Y, Mayeux R: The influence of smoking on the risk of Alzheimer's disease. Neurology 1999;52:1408-1412.

30 Brenner DE, Kukull WA, Stergachis A, Van Belle G, Bowen JD, McCormick WC, Teri L, Larson EB: Postmenopausal estrogen replacement therapy and the risk of Alzheimer's disease: A population-based case-control study. Am J Epidemiol 1994; 140:262-267.

31 Kawas C, Resnick S, Morrison A, Brookmeyer R, Corrada M, Zonderman A, Bacal C, Lingle DD, Metter E: A prospective study of estrogen replacement therapy and the risk of developing Alzheimer's disease: The Baltimore Longitudinal Study of Aging. Neurology 1997;48:15171521
32 Tang MX, Jacobs D, Stern Y, Marder K, Schofield P, Gurland B, Andrews H, Mayeux R: Effect of oestrogen during menopause on risk and age at onset of Alzheimer's disease. Lancet 1996;348:429-432.

33 Hofman A, Ott A, Breteler MM, Bots ML, Slooter AJ, Van Harskamp F, Van Duijn CM, Van Broeckhoven C, Grobbee DE: Atherosclerosis, apolipoprotein $\mathrm{E}$, and prevalence of dementia and Alzheimer's disease in the Rotterdam Study. Lancet 1997;349:151-154.

34 Hendrie HC, Ogunniyi A, Hall KS, Baiyewu O, Unverzagt FW, Gureje O, Gao S, Evans RM, Ogunseyinde AO, Adeyinka AO, Musick B, Hui SL: Incidence of dementia and Alzheimer disease in 2 communities: Yoruba residing in Ibadan, Nigeria, and African Americans residing in Indianapolis, Indiana. JAMA 2001;285: 739-747.

35 Van Duijn CM, Clayton D, Chandra V, Fratiglioni L, Graves AB, Heyman A, Jorm AF, Kokmen E, Kondo K, Mortimer JA, et al: Familial aggregation of Alzheimer's disease and related disorders: A collaborative re-analysis of case-control studies. EURODEM Risk Factors Research Group. Int J Epidemiol 1991; 20:S13-20.

36 Plassman BL, Breitner JC: Recent advances in the genetics of Alzheimer's disease and vascular dementia with an emphasis on gene-environment interactions. J Am Geriatr Soc 1996; 44:1242-1250

37 Van Duijn CM, Farrer LA, Cupples LA, Hofman A: Genetic transmission of Alzheimer's disease among families in a Dutch population based study. J Med Genet 1993;30:640-646.

38 Rao VS, Van Duijn CM, Connor-Lacke L, Cupples LA, Growdon JH, Farrer LA: Multiple etiologies for Alzheimer disease are revealed by segregation analysis. Am J Hum Genet 1994; 55:991-1000.

39 Croes EA, Dermaut B, Van der Cammen TJ, Van Broeckhoven C, Van Duijn CM: Genetic testing should not be advocated as a diagnostic tool in familial forms of dementia. Am J Hum Genet 2000;67:1033-1035.

40 Cruts M, Van Broeckhoven C: Molecular genetics of Alzheimer's disease. Ann Med 1998; 30:560-565.

41 Cruts M, Van Duijn CM, Backhovens H, Van den Broeck M, Wehnert A, Serneels S, Sherrington R, Hutton M, Hardy J, St George-Hyslop PH, Hofman A, Van Broeckhoven C: Estimation of the genetic contribution of presenilin- 1 and -2 mutations in a population-based study of presenile Alzheimer disease. Hum Mol Genet 1998;7:43-51.

42 Tol J, Roks G, Slooter AJ, Van Duijn CM: Genetic and environmental factors in Alzheimer's disease. Rev Neurol (Paris) 1999;155: S10-16.

43 Pericak-Vance MA, Bebout JL, Gaskell PC Jr, Yamaoka LH, Hung WY, Alberts JM, Walker AP, Bartlett RJ, Haynes CA, Welsh KA, et al: Linkage studies in familial Alzheimer disease: Evidence for chromosome 19 linkage. Am J Hum Genet 1991;48:1034-1050.
44 Strittmatter WJ, Saunders AM, Schmechel D, Pericak-Vance M, Enghild J, Salvesen GS, Roses AD: Apolipoprotein E: High-avidity binding to beta-amyloid and increased frequency of type 4 allele in late-onset familial Alzheimer disease. Proc Natl Acad Sci USA 1993;90:1977-1981.

45 Van Duijn CM, De Knijff P, Cruts M, Wehnert A, Havekes LM, Hofman A, Van Broeckhoven $\mathrm{C}$ : Apolipoprotein E4 allele in a populationbased study of early-onset Alzheimer's disease. Nat Genet 1994;7:74-78.

46 Liddell MB, Lovestone S, Owen MJ: Genetic risk of Alzheimer's disease: Advising relatives. Br J Psychiatry 2001;178:7-11.

47 Farrer LA, Cupples LA, Haines JL, Hyman B, Kukull WA, Mayeux R, Myers RH, PericakVance MA, Risch N, Van Duijn CM: Effects of age, sex, and ethnicity on the association between apolipoprotein E genotype and Alzheimer disease. A meta-analysis. APOE and Alzheimer Disease Meta-Analysis Consortium. JAMA 1997;278:1349-1356.

48 Meyer MR, Tschanz JT, Norton MC, WelshBohmer KA, Steffens DC, Wyse BW, Breitner JC: APOE genotype predicts when - not whether - one is predisposed to develop Alzheimer disease. Nat Genet 1998;19:321-322.

49 Golde TE, Eckman CB, Younkin SG: Biochemical detection of Abeta isoforms: Implications for pathogenesis, diagnosis, and treatment of Alzheimer's disease. Biochim Biophys Acta 2000;1502:172-187.

50 Hardy J: Amyloid, the presenilins and Alzheimer's disease. Trends Neurosci 1997;20: 154-159.

51 Tandon A, Rogaeva E, Mullan M, St GeorgeHyslop PH: Molecular genetics of Alzheimer's disease: The role of beta-amyloid and the presenilins. Curr Opin Neurol 2000;13:377-384.

52 Selkoe DJ: The origins of Alzheimer disease: A is for Amyloid. JAMA 2000;283:1615-1617.

53 Selkoe DJ: Alzheimer's disease: A central role for amyloid. J Neuropathol Exp Neurol 1994; 53:438-447.

54 Rosenberg RN: A causal role for amyloid in Alzheimer's disease: The end of the beginning. Neurology 1993;43:851-856.

55 Rosenberg RN: The molecular and genetic basis of AD: The end of the beginning: The 2000 Wartenberg lecture. Neurology 2000;54:20452054

56 Younkin SG: The role of A beta 42 in Alzheimer's disease. J Physiol Paris 1998;92:289_ 292.

57 St George-Hyslop PH: Genetic factors in the genesis of Alzheimer's disease. Ann NY Acad Sci 2000;924:1-7.

58 Cao X, Sudhof TC: A transcriptively active complex of APP with Fe65 and histone acetyltransferase Tip60. Science 2001;293:115-120. 
59 Citron M, Vigo-Pelfrey C, Teplow DB, Miller C, Schenk D, Johnston J, Winblad B, Venizelos N, Lannfelt L, Selkoe DJ: Excessive production of amyloid beta-protein by peripheral cells of symptomatic and presymptomatic patients carrying the Swedish familial Alzheimer disease mutation. Proc Natl Acad Sci USA 1994. 91:11993-11997.

60 Haass C, Hung AY, Selkoe DJ, Teplow DB Mutations associated with a locus for familial Alzheimer's disease result in alternative processing of amyloid beta-protein precursor. $\mathrm{J}$ Biol Chem 1994;269:17741-17748.

61 Tamaoka A, Odaka A, Ishibashi Y, Usami M, Sahara N, Suzuki N, Nukina N, Mizusawa H, Shoji S, Kanazawa I, et al: APP717 missense mutation affects the ratio of amyloid beta protein species (A beta 1-42/43 and a beta 1-40) in familial Alzheimer's disease brain. J Biol Chem 1994;269:32721-32724.

62 Eckman CB, Mehta ND, Crook R, Perez-Tur J, Prihar G, Pfeiffer E, Graff-Radford N, Hinder P, Yager D, Zenk B, Refolo LM, Prada CM, Younkin SG, Hutton M, Hardy J: A new pathogenic mutation in the APP gene (I716V) increases the relative proportion of $\mathrm{A}$ beta 42(43). Hum Mol Genet 1997;6:2087-2089.

63 Jarrett JT, Lansbury PT Jr: Seeding 'onedimensional crystallization' of amyloid: A pathogenic mechanism in Alzheimer's disease and scrapie? Cell 1993;73:1055-1058.

64 Scheuner D, Eckman C, Jensen M, Song X, Citron M, Suzuki N, Bird TD, Hardy J, Hutton M, Kukull W, Larson E, Levy-Lahad E, Viitanen M, Peskind E, Poorkaj P, Schellenberg G, Tanzi R, Wasco W, Lannfelt L, Selkoe d, Younkin S: Secreted amyloid beta-protein similar to that in the senile plaques of Alzheimer's disease is increased in vivo by the presenilin 1 and 2 and APP mutations linked to familial Alzheimer's disease. Nat Med 1996;2:864-870.

65 Citron M, Westaway D, Xia W, Carlson G, Diehl T, Levesque G, Johnson-Wood K, Lee M, Seubert P, Davis A, Kholodenko D, Motter R, Sherrington R, Perry B, Yao H, Strome R, Lieberburg I, Rommens J, Kim S, Schenk D, Fraser P, St George-Hyslop P, Selkoe DJ: Mutant presenilins of Alzheimer's disease increase production of 42-residue amyloid beta-protein in both transfected cells and transgenic mice Nat Med 1997;3:67-72.
66 Borchelt DR, Thinakaran G, Eckman CB, Lee MK, Davenport F, Ratovitsky T, Prada CM, Kim G, Seekins S, Yager D, Slunt HH, Wang R, Seeger M, Levey AI, Gandy SE, Copeland NG, Jenkins NA, Price DL, Younkin SG, Sisodia SS: Familial Alzheimer's disease-linked presenilin 1 variants elevate Abeta1-42/1-40 ratio in vitro and in vivo. Neuron 1996;17: 1005-1013.

67 Xia W, Zhang J, Kholodenko D, Citron M, Podlisny MB, Teplow DB, Haass C, Seubert P, Koo EH, Selkoe DJ: Enhanced production and oligomerization of the 42-residue amyloid beta-protein by Chinese hamster ovary cells stably expressing mutant presenilins. J Biol Chem 1997;272:7977-7982.

68 Mehta ND, Refolo LM, Eckman C, Sanders S, Yager D, Perez-Tur J, Younkin S, Duff K, Hardy J, Hutton M: Increased Abeta42(43) from cell lines expressing presenilin 1 mutations. Ann Neurol 1998;43:256-258.

69 Wisniewski T, Golabek A, Matsubara E, Ghiso J, Frangione B: Apolipoprotein E: Binding to soluble Alzheimer's beta-amyloid. Biochem Biophys Res Commun 1993;192:359-365.

70 Poirier J: Apolipoprotein E and Alzheimer's disease. A role in amyloid catabolism. Ann NY Acad Sci 2000;924:81-90.

71 Davis JN, 2nd, Chisholm JC: The 'amyloid cascade hypothesis' of AD: Decoy or real McCoy? Trends Neurosci 1997;20:558-559.

72 Joseph J, Shukitt-Hale B, Denisova NA, Martin A, Perry G, Smith MA: Copernicus revisited: Amyloid beta in Alzheimer's disease. Neurobiol Aging 2001;22:131-146.

73 Smith MA, Joseph JA, Perry G: Arson. Tracking the culprit in Alzheimer's disease. Ann NY Acad Sci 2000;924:35-38.

74 Naslund J, Haroutunian V, Mohs R, Davis KL, Davies P, Greengard P, Buxbaum JD: Correlation between elevated levels of amyloid betapeptide in the brain and cognitive decline. JAMA 2000;283:1571-1577.

75 Butcher J: Alzheimer's amyloid hypothesis gains support. Lancet 2000;356:2161.

76 Davies P: A very incomplete comprehensive theory of Alzheimer's disease. Ann NY Acad Sci 2000;924:8-16.

77 Mesulam MM: A plasticity-based theory of the pathogenesis of Alzheimer's disease. Ann NY Acad Sci 2000;924:42-52.

78 Christen Y: Oxidative stress and Alzheimer disease. Am J Clin Nutr 2000;71:621S-629S.
79 de la Torre JC: Impaired cerebromicrovascular perfusion. Summary of evidence in support of its causality in Alzheimer's disease. Ann NY Acad Sci 2000;924:136-152.

80 Rogers J, Webster S, Lue LF, Brachova L, Civin WH, Emmerling M, Shivers B, Walker D, McGeer P: Inflammation and Alzheimer's disease pathogenesis. Neurobiol Aging 1996;17: 681-686.

81 Campion D, Dumanchin C, Hannequin D, Dubois B, Belliard S, Puel M, Thomas-Anterion $\mathrm{C}$, Michon A, Martin C, Charbonnier F, Raux G, Camuzat A, Penet C, Mesnage V, Martinez M, Clerget-Darpoux F, Brice A, Frebourg T: Early-onset autosomal dominant Alzheimer disease: Prevalence, genetic heterogeneity, and mutation spectrum. Am J Hum Genet 1999;65:664-670.

82 Slooter AJ, Breteler MB, Ott A, Van Broeckhoven C, Van Duijn CM: APOE genotyping in differential diagnosis of Alzheimer's disease. Lancet 1996;348:334.

83 Schenk D, Barbour R, Dunn W, Gordon G, Grajeda H, Guido T, Hu K, Huang J, JohnsonWood K, Khan K, Kholodenko D, Lee M, Liao Z, Lieberburg I, Motter R, Mutter L, Soriano F, Shopp G, Vasquez N, Vandevert C, Walker S, Wogulis M, Yednock T, Games D, Seubert P: Immunization with amyloid-beta attenuates Alzheimer-disease-like pathology in the PDAPP mouse. Nature 1999;400:173-177.

84 Morgan D, Diamond DM, Gottschall PE, Ugen KE, Dickey C, Hardy J, Duff K, Jantzen P, DiCarlo G, Wilcock D, Connor K, Hatcher J, Hope C, Gordon M, Arendash GW: A beta peptide vaccination prevents memory loss in an animal model of Alzheimer's disease. Nature 2000;408:982-985.

85 Janus C, Pearson J, McLaurin J, Mathews PM, Jiang Y, Schmidt SD, Chishti MA, Horne P, Heslin D, French J, Mount HT, Nixon RA, Mercken M, Bergeron C, Fraser PE, St GeorgeHyslop P, Westaway D: A beta peptide immunization reduces behavioural impairment and plaques in a model of Alzheimer's disease. Nature 2000;408:979-982.

86 Chen G, Chen KS, Knox J, Inglis J, Bernard A, Martin SJ, Justice A, McConlogue L, Games D, Freedman SB, Morris RG: A learning deficit related to age and beta-amyloid plaques in a mouse model of Alzheimer's disease. Nature 2000;408:975-979. 